\title{
A Forced Oscillation System for Damping Derivative Measurement in the T-38 Trisonic Wind Tunnel
}

\author{
Marija Samardžić ${ }^{1)}$ \\ Dragan Marinkovski ${ }^{1)}$ \\ Dušan Ćurčić ${ }^{1)}$
}

\begin{abstract}
A forced oscillation system for the measurement of damping derivative due to an aircraft or missile model oscillatory motion in a wind tunnel test section is described. The forced oscillation technique is used for dynamic stability derivatives measurements in the T-38 wind tunnel. Two full-model apparatuses for oscillatory experiments in pitch/yaw and in roll are shown. Oscillatory motion is imparted to the model by hydraulic driving mechanism. Control unit operates directly with hydraulic servo-valve and provides a desired oscillatory motion of the model.
\end{abstract}

Key words: aerodynamic derivatives, stability derivatives, forced oscillations, oscillatory motion, wind tunnel.

\section{Introduction}

$\mathrm{R}$ ELIABLE estimation of damping and other dynamic stability derivatives are very essential for aircraft design as they have a big effect on aircraft flight quality and control. The concept of stability derivatives is related to the traditional form of equations of motion where the result of a small disturbance from the equilibrium flight condition is described by linear superposition of contributions caused by the change in various attitude variables and their time rates to change. Up to now, determination of stability derivatives has mainly relied on dynamic wind tunnel experiments and semiempirical method. The dynamic derivatives can be determined from wind tunnel experiments using aircraft models describe a rotational or oscillatory motion in relation to a parallel air stream. The measurements can be carried out according to two main principles: by measuring forces and moments when relatively motion between the model and air stream is given, or by measuring the relative motion when forcing or restraining forces and moments are given [1-4]. The forced oscillation techniques are the most often used. In these experiments a preselected motion is imparted to the model and forces and moments between the model and the forcing part of the dynamic apparatus are measured. The model motion can be angular or translational and is most often harmonic, in which case the derivatives are obtained from the in-phase and out-of-phase components of the measured aerodynamic reactions. The oscillatory motion is induced to a model in one degree of freedom (the primary degree of freedom). The reaction measured in the primary degree of freedom determines direct damping derivative. Such experiments can be performed using either constant oscillatory moment or constant oscillatory displacement. If an electromagnetic drive is used, the amplitude of the excitation moment (or force) is usually constant and the amplitude of the displacement depends on the total damping in the system. If a mechanical or hydraulic drive is used, displacement amplitude is then kept constant and amplitude of the excitation moment (or force) is adjusted as needed.

In addition to the parameters which usually are varied during static wind tunnel tests, such as Mach and Reynolds numbers, model angle of attack, and so on, dynamic experiments require in general the variation of two additional parameters, amplitude of the model oscillatory motion and reduced frequency. The equation for determination of the reduced frequency, $k$, may be written as:

$$
k=\omega c / 2 V
$$

where $\omega$ is angular velocity of the model, $c$ is reference length in longitudinal motion and $V$ is free stream velocity. In the case of continuous roll parameters $\omega$ and $c$ are replaced by dimensional roll velocity parameter $p b / 2 V$ where $p$ is rolling velocity and $b$ is reference length in lateral motion. Since the free stream velocity in the wind tunnel test section is usually fixed by Reynolds and Mach number the angular velocity $\omega$ or roll velocity $p$ have usually to be much higher than full scale.

Models in wind tunnels test section usually are mechanically suspended. This introduces the mechanical damping of the suspension into the analysis. Thus a measurement of aerodynamic damping cannot be performed directly. Aerodynamic damping is obtained as a difference between the damping measured in the presence of aerodynamic forces ("wind-on run") and in their absence ("tare run"). At low supersonic speeds the tare run damping is of the order of only one percent or so of the aerodynamic damping, but that at higher speeds its effect becomes rapidly more important, and can be, at hypersonic speeds, as large as aerodynamic damping to be measured. The experimental equipment should be designed in such way that the mechanical damping is small as compared to the aerodynamic damping to be measured and thus tare run data constitute only a minor correction to the wind-on run data.

\footnotetext{
1) Military Technical Institute (VTI), Ratka Resanovića 1, 11132 Belgrade, SERBIA

Correspondence to: Marija Samardžić; e-mail: majasam@ptt.rs
} 


\section{Technique for damping derivative measurement in the T-38 wind tunnel}

The T-38 test facility is blowdown-type pressurized wind tunnel with $1.5 \times 1.5 \mathrm{~m}^{2}$ square test section [5]. This wind tunnel enables testing in three speed ranges (subsonic, transonic and supersonic speed range). Mach number in the range 0.2-4.0 can be achieved in the test section. Value of Reynolds number in the experiments may be up to $110 \times 10^{6}$ per meter. Stagnation pressure in the test section can be maintained between $1.1 \times 10^{5} \mathrm{~Pa}$ and $15 \times 10^{5} \mathrm{~Pa}$, depending on Mach number. Run times are up to $60 \mathrm{~s}$, which depend on Mach number and stagnation pressure.

The forced oscillation technique is used for the measurement of dynamic stability derivatives in the T-38 wind tunnel. The implementation of this technique in the dynamic measurements required design and manufacture of the two apparatus: the first one for measurements in the pitch/yaw oscillatory test and the second one for the roll oscillatory tests $[6,7]$. The apparatuses are full-model forced oscillation apparatuses.

The model is forced to oscillate at constant amplitude. To obtain the direct damping derivative due to model oscillatory motion the amplitude of the excitation moment, amplitude of the model angular oscillatory motion and phase shift between these quantities have to be measured. A typical dynamic wind tunnel run includes two stages: wind-on run and tare run. In the tare run the model is forced to oscillate but the wind tunnel is not running. This measurement enables determination of the mechanical damping. In the wind-on run model is oscillated at the same frequency as in the tare run but with the wind tunnel running. In the wind-on run the total damping is obtained. The damping derivates are obtained by subtracting tare run data from wind-on run data.

The damping derivate is given by (2):

$$
J_{d}=-\left(\frac{|M| \sin \eta}{|\theta| \omega}-\frac{\left|M_{0}\right| \sin \eta_{0}}{\left|\theta_{0}\right| \omega_{0}}\right)
$$

where $J_{d}$ is damping derivative, $|M|$ is amplitude of the excitation moment, $|\theta|$ is amplitude of the model angular oscillatory motion, $\eta$ is phase shift between oscillatory motion of the model and excitation moment. Values with index " 0 " are measured in the tare run [8].

\section{Performance parameters of the apparatuses for damping derivative measurements in the T-38 wind tunnel}

Performance parameters of the apparatus for damping derivative measurements are determined based on:

- Size of the wind tunnel test section and speed range which can be achieved in the experiments.

- Maximum dynamic pressure. Value of the maximum dynamic pressure should not exceed the value corresponding to the highest Reynolds number that is compatible with the wind tunnel run duration of not less than 10 seconds and should be realistic in terms of the maximum load-carry capacity of the apparatuses sting.

- Aerodynamic wind tunnel interference. An often used criterion requires that the model span does not exceed $75 \%$ of the effective wind tunnel width.

- Maximum distance from the center of the oscillation to the model base. For a given model base diameter and a given amplitude of oscillation in pitch or yaw this distance determines the size of the apparatuses sting at the model base and therefore the maximum allowable loading that is compatible with the stress limitations of the sting.
- Model bore diameter. The bore diameter effect on loadcarrying capability of the sting, availability of sufficient clearance for the oscillatory motion in the presence of the sting deflection due to the static loads, sting stiffness with its effect on the plunging resonance frequency of the model-sting combination.

- Static aerodynamic loads. To obtain maximum aerodynamic loads a combination of the maximum values of the non-dimensional aerodynamic coefficients, maximum envisaged model dimensions and maximum dynamic pressure have to be considered. However, for fullmodel dynamic experiments in which the apparatus sting often has to be much smaller than for the corresponding static test, it is unrealistic to consider a combination of all these maximum values occurring simultaneously.

In a blowdown-pressurized wind tunnel in which air is blow down from a high-pressure storage to the atmosphere, the occurrence of the so-called starting and stopping loads has to be taken into account at supersonic speeds [9]. This could be done using a smaller model for the experiment, by reducing (at supersonic speeds) the maximum angles of attack and sideslip or by achieving an extra safety factor in calculation of the apparatuses.

Performance parameters of the apparatuses in the T-38 wind tunnel, according all terms mentioned above are shown in Table 1.

Table 1. Performnance parameters of the apparatuses

\begin{tabular}{|c|c|}
\hline Model oscillation amplitude & $0.25-1.5^{\circ}$ \\
\hline Model oscillation frequency & $1-15 \mathrm{~Hz}$ \\
\hline \multirow{2}{*}{ Sting diameter } & Roll apparatus: $76 \mathrm{~mm}$ \\
\cline { 2 - 2 } & Pitch/yaw apparatus: $50 \times 70 \mathrm{~mm}^{2}$ \\
\hline Maximum normal force & $10000 \mathrm{~N}$ \\
\hline
\end{tabular}

\section{The T-38 wind tunnel system for damping derivative measurement}

The system for damping derivative measurement in the T-38 wind tunnel consists of: forced oscillation apparatuses, hydraulic unit, apparatus control unit (pitch/yaw and roll), wind tunnel control system, data acquisition system and data reduction system (Fig.1).

The forced oscillation apparatuses include following elements:

- Sting support system.

- Elastic suspension mechanism characterized by its relatively high compliance in the primary degree of freedom and its high stiffness in the other degrees. Relatively high compliance in the primary degree of freedom permits the primary motion of the model, while high stiffness in the other degrees is necessary to withstand the aerodynamic loads with negligible resultant deflections.

- Five-component balance for the measurements of the aerodynamic loads, excitation moment in the primary degree of freedom, as well as secondary reactions caused by the primary motion.

- Hydraulic driving mechanism to impart the oscillatory primary motion to the model.

- Sensor to detect the primary motion.

The pitch/yaw apparatus is shown in Figures 2 and 3. Elastic suspension mechanism consists of a pair of crossflexures ensuring the necessary compliance in pitch or yaw, depending on the model orientation on the five-component 
balance. To obtain a complete set of derivatives in pitch and yaw, the apparatus has to be used twice, with the apparatus rotated $90^{\circ}$ around its longitudinal axis (in relation to both the model and the sting support) between the experiments. The primary oscillatory motion is imparted to the model by the hydraulic driving mechanism in which the piston moves and applies the driving force to the actuator arm. Actuator arm is linked to the moving end of the cross-flexures. The fivecomponent balance is mounted inside the actuator arm between cross-flexures of the elastic suspension mechanism. This balance is monoblock strain gauge balance and it is used for the measurements of five components of the aerodynamic loads: side force, normal force, rolling moment, pitching moment and yawing moment $[10,11]$. The hydraulic actuator is controlled by the hydraulic servo-valve located at the apparatus sting base. The apparatus includes the following sensors: primary oscillatory motion sensor, feedback position sensor and excitation moment sensor. Two primary oscillatory motion sensors are realized on the cross-flexures of the elastic suspension mechanism. Excitation moment sensor is realized on the actuator arm. Also, excitation moment, as well as secondary reaction caused by the model oscillatory motion can be measured by corresponding balance measuring bridge on the five-component balance.

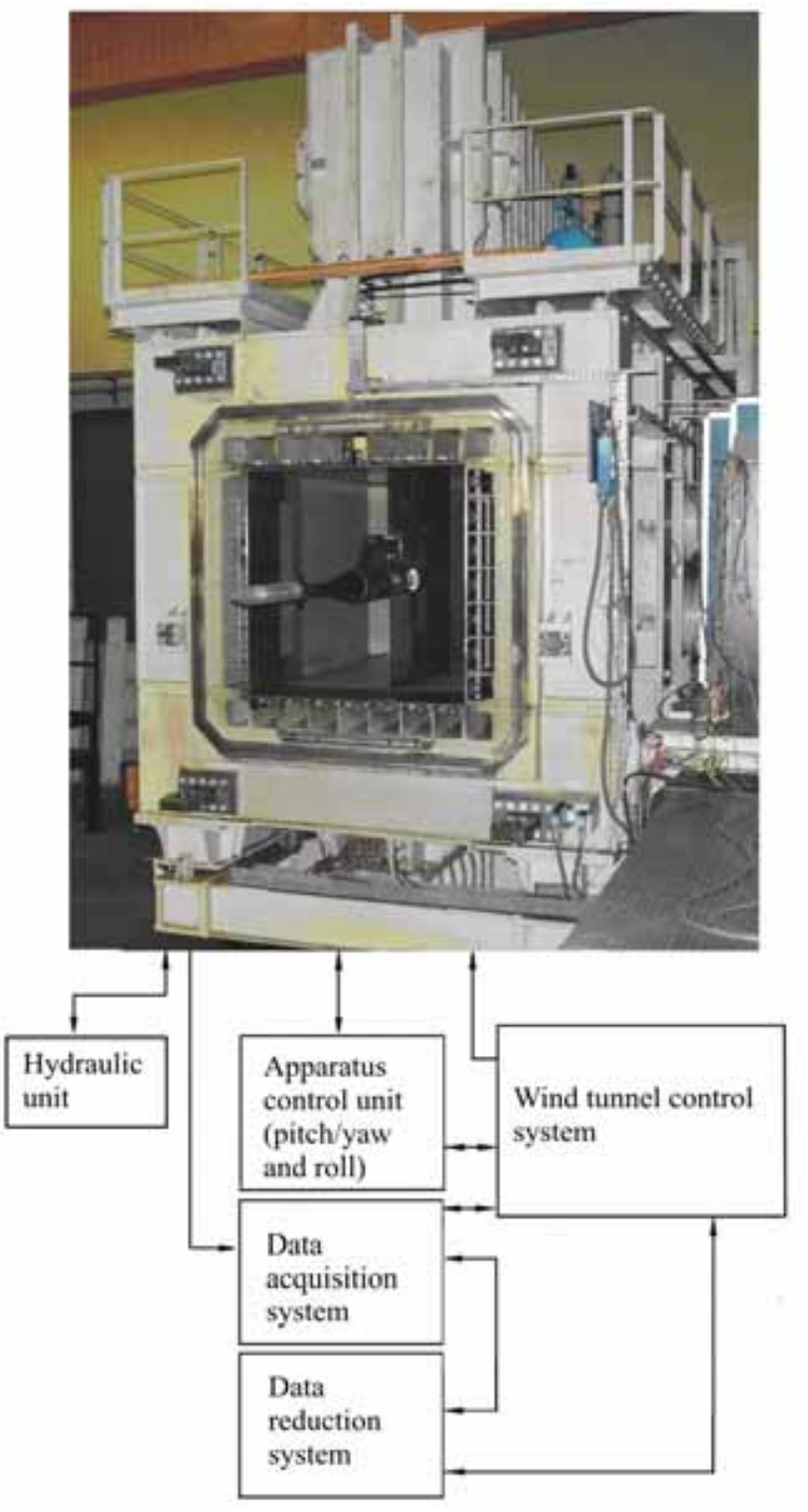

Figure 1. System for damping derivative measurement

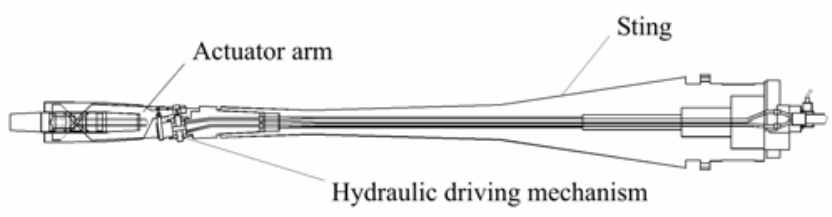

Figure 2. Scheme of the pitch/yaw apparatus

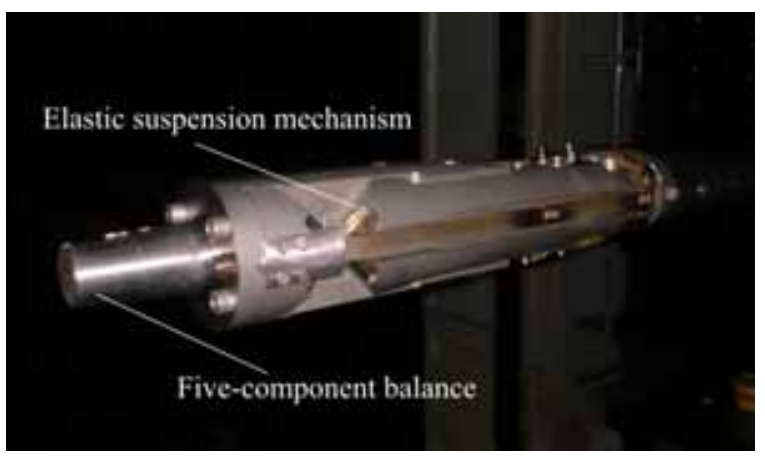

Figure 3. Front part of thepitch/yaw apparatus

The roll apparatus is shown in Figures 4 and 5. The elastic suspension mechanism consists of two ring jointed by axially oriented beams equally spaced around the periphery of the rings. The oscillatory motion is imparted via drive shaft whose front end is attached to the five-component balance. The same five-component balance is used for the experiments with both apparatuses (pitch/yaw apparatus and roll apparatus). The balance is mounted on the front end of the drive shaft, protruding forward thought the cavity surrounded by the suspension beams, while the aft part of suspension mechanism is firmly fixed to the end of the sting. Hydraulic driving mechanism is located at the rear end of the sting. The hydraulic actuator is controlled by the hydraulic servo-valve located at the apparatus sting base. The roll apparatus includes the following sensors: primary oscillatory motion sensor, feedback position sensor and excitation moment sensor. Two primary oscillatory motion sensors are mounted on the elastic suspension mechanism. Excitation moment sensor is realized on the drive shaft. Excitation moment can also be measured by rolling moment measuring bridge on the five-component balance.

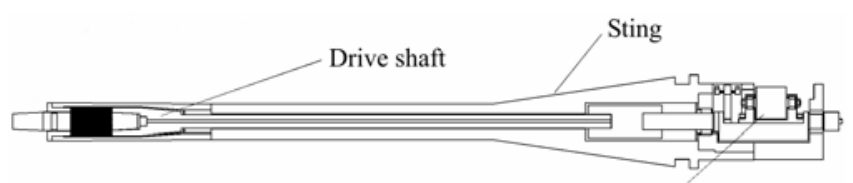

Hydraulic driving mechanism

Figure 4. Scheme of the roll apparatus

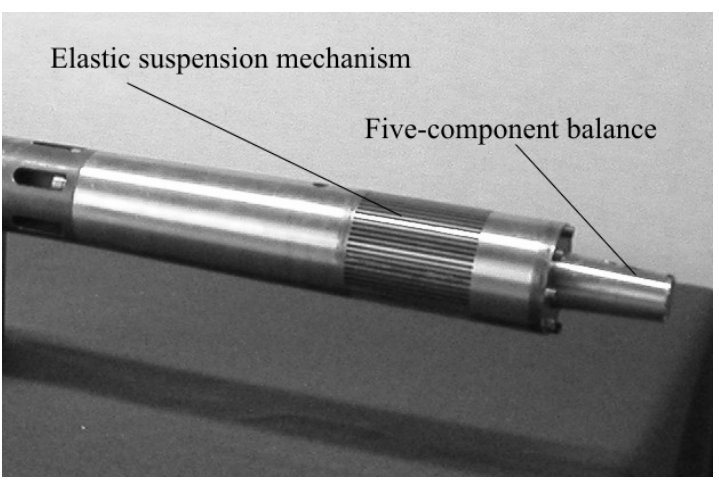

Figure 5. Front part of the roll apparatus 


\section{Hydarulic driving mechanism of the apparatuses}

Hydraulic driving mechanism of the pitch/yaw apparatus is shown in Fig.6. The body of the hydraulic driving mechanism and a pair of cross-flexures are designed and manufactured in one piece. The hydraulic driving mechanism is designed to provide a large excitation moment for the model angular oscillatory motion in pitch and yaw. The required value of the excitation moment is determined as a sum of the moment to overcome the external aerodynamic loads, resisting moment of the elastic suspension mechanism and resisting moment of the assembly for adjustment stiffness of the pitch/yaw apparatus. In the T-38 wind tunnel test maximum amplitude of the model oscillatory motion of $1.5^{\circ}$ can be achieved.
Hydraulic driving mechanism of the roll apparatus is shown in Fig.7. The driving mechanism main task is to achieve a large enough excitation moment for the model oscillatory motion with maximum amplitude of $1.5^{\circ}$. The required value of the excitation moment is determined as a sum of the moment to overcome the external aerodynamic loads, moment to roll the elastic suspension mechanism and assembly for adjustment stiffness of the roll apparatus and resisting moments in the bearings. The hydraulic actuator body is rigidly connected to the drive shaft. The piston of the hydraulic actuator is connected to the support of the hydraulic driving mechanism and performs oscillatory motion of very small amplitudes around the apparatus transverse axis.

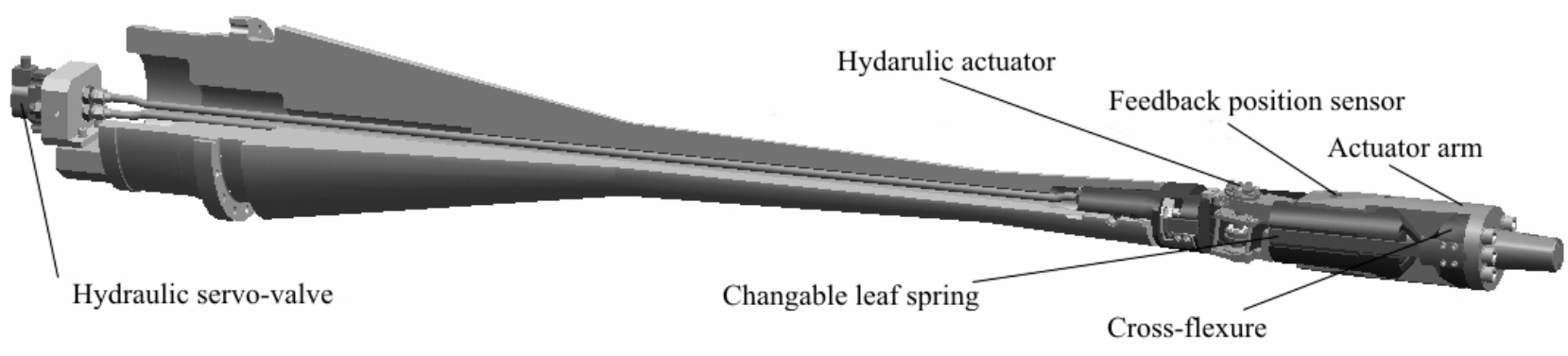

Figure 6. Hydraulic driving mechanism of the pitch/yaw apparatus

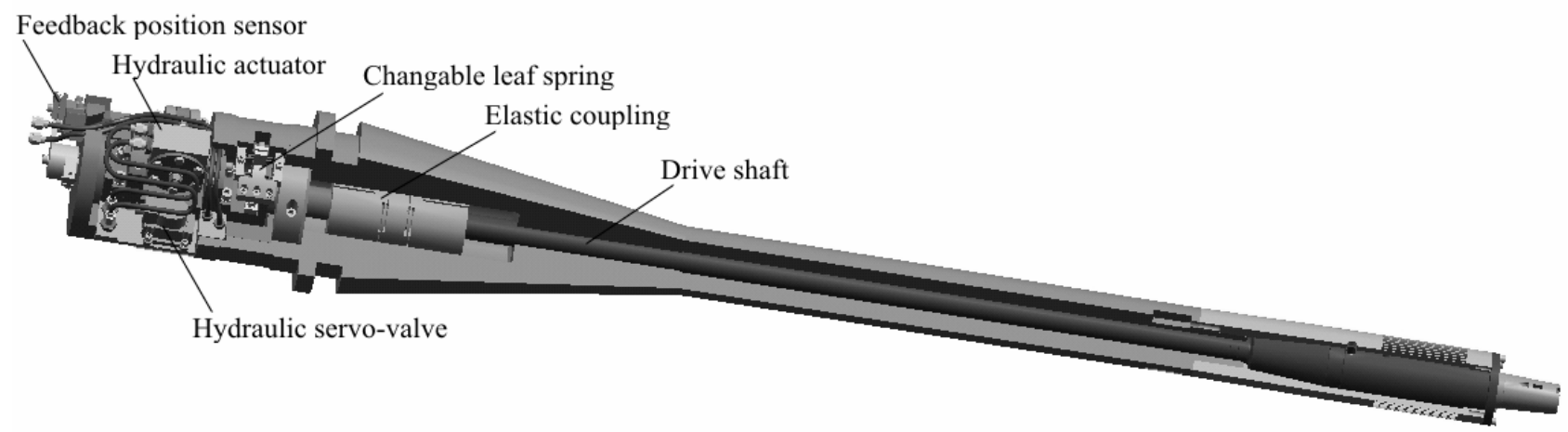

Figure 7. Hydraulic driving mechanism of the roll apparatusThe power supply of the hydraulic driving mechanism is carried out from the hydraulic unit with a nominal operation pressure of $210 \times 10^{5} \mathrm{~Pa}$ and capacity of $15 \times 10^{-3} \mathrm{~m}^{3}$ per minute.

The apparatuses control and monitoring is performed by the control unit which operates directly with the hydraulic servo- valves. The control unit enables the following types of the model movement in the selected degree of freedom:

- Harmonic oscillatory motion with given constant amplitude and frequency.

- Step-by-step motion with given maximum amplitude and step.

- Bouncing movement.

Block diagram of the hydraulic driving mechanism for the apparatuses is shown in Fig.8.

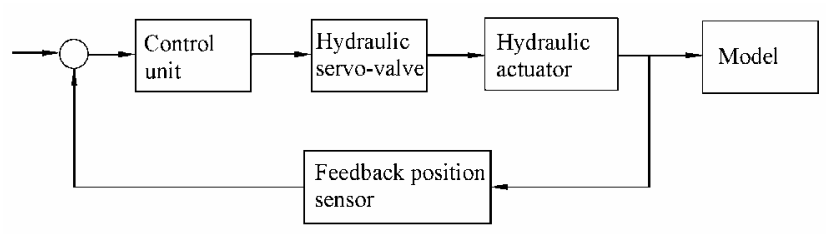

Figure 8. Block diagram of the hydraulic driving mechanism
By alternating activation of the hydraulic servo-valve the oil is led from side to side of the piston of the hydraulic actuator. The feedback position sensor sends information about the actual position of the actuator arm on the pitch/yaw apparatus and actual position of the drive shaft on the roll apparatus to the control unit, Figures 9 and10.

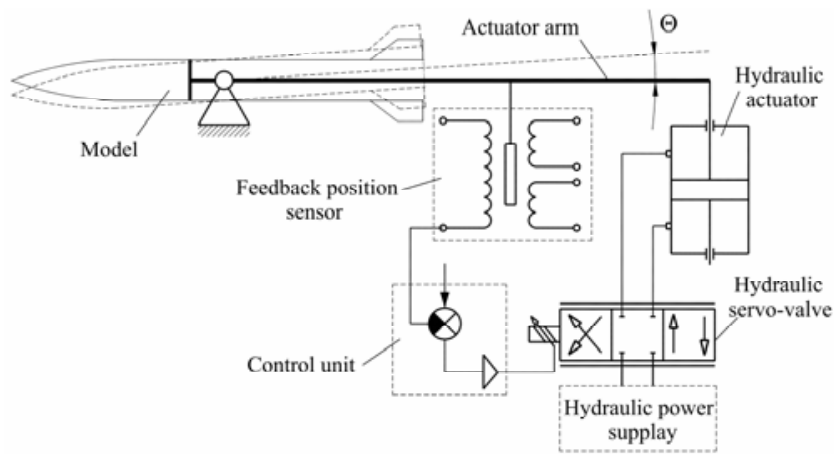

Figure 9. Kinematic scheme of the hydraulic driving mechanism of the pitch/yaw apparatus 


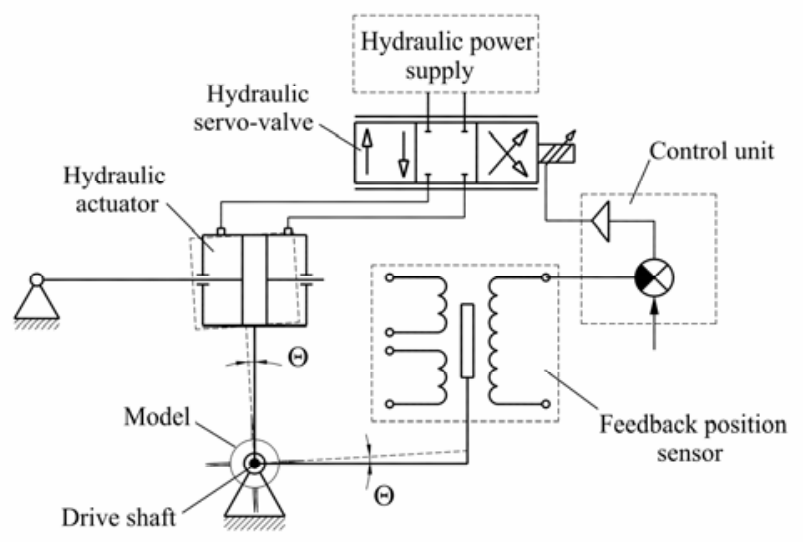

Figure 10. Kinematic scheme of the hydraulic driving mechanism of the roll apparatus

The feedback position sensors are linear position sensor, LVDT type and MHR series produced by Schaevitz (250 MHR series).

The hydraulic servo-valves of the same type are installed on the both apparatuses. Those are MOOG type 30 servovalves series 31 [12].

Hydraulic driving mechanisms of the pitch/yaw and roll apparatuses provide the model angular oscillatory motion with required parameters in the wind tunnel test section.

\section{Acknowledgment}

This study was supported by the Military Technical Institute (VTI) and the Ministry of Education, Science and Technological Development of the Republic of Serbia (project number TR 36050).

\section{References}

[1] ORLIK-RÜCKEMAN,K.J.: Review of techniques for the determination of dynamic stability parameters in wind tunnels, AGARD-LS-114, The Advisory Group for Aerospace Research and Development, NATO Research and Technology Organization, Brussels, BELGIUM, 1981.

[2] O'LEARY,C.O.: Rotary and oscillatory experiments, AGARD-AR305, The Advisory Group for Aerospace Research and Development, NATO Research and Technology Organization, Brussels, BELGIUM, 1996.
[3] TOMEK,D.M., SEWALL,W.G., MASON,S.E., SZCHUR,B.W.A.: The next generation of high-speed dynamic stability wind tunnel testing, (invited), in Proc. 25th AIAA Aerodynamic Measurement Technology and Ground Testing Conference, San Francisco, California, 2006, pp. 1-19, Paper no. AIAA 2006-3148.

[4] HANFF,E.S.: Direct forced-oscillation techniques for the determination of stability derivatives in wind tunnels, AGARD-LS114, The Advisory Group for Aerospace Research and Development, NATO Research and Technology Organization, Brussels, BELGIUM, 1981.

[5] MEDVED,B., ELFSTROM,G.M.: The Yugoslav $1.5 \mathrm{~m}$ Trisonic blowdown wind tunnel, AIAA Paper, no. 86-0746-CP American Institute of Aeronautics and Astronautics, Reston, Virginia, USA, 1986.

[6] SAMARDŽIĆ,M., ANASTASIJEVIĆ,Z., MARINKOVSKI,D., ISAKOVIĆ,J., TANČIĆ,Lj.: Measurement of pitch-and roll-damping derivativesusing using semicondusctor five-component strain gauge balance, Proc. IMechE Part G: J. Aerospace Eng., Nov. 2012, Vol.226, No.11, pp.1401-1411.

[7] SAMARDŽIĆ,M., $\quad$ ISAKOVIĆ,J., $\quad$ ANASTSIJEVIĆ,Z., MARINKOVSKI,D.: Apparatus for measurement of pitch and yaw damping derivatives in high Reynolds number blowdown wind tunnel, Measurement, 2013, Vol.46, pp. 2457-2466.

[8] SAMARDŽIĆ,M., ISAKOVIĆ,J., MILOŠ,M.: Experimental methodology for determining stability derivatives in the T-38 wind tunnel, in Proc. 31st Danubia-Adria Symposium on Advances in Experimental Mechanics, Kempten, GERMANY, 2014, pp. 102-105.

[9] VUKOVIĆ,Đ., $\quad$ ĆURČIĆ,D., DAMLJANOVIĆ,D., SAMARDŽIĆ,M., VITIĆ,A.: Living with supersonic starting loads in the T-38 Trisonic Wind Tunnel of VTI, in Proc. 29th Congress of the International Council of the Aeronautical Sciences, St. Petersburg, RUSSIA, 2014, pp. 1-9.

[10] ANASTASIJEVIĆ,Z., SAMARDŽIĆ,M., MARINKOVSKI,D.: Application of semiconductor strain gauges in measurements of dynamic stability derivatives in the T-38 wind tunnel, in Proc. 26th Congress of the International Council of the Aeronautical Sciences, Anchorage, Alaska, USA, 2008, pp. 1-7.

[11] SAMARDŽIĆ,M., VUKOVIĆ,Đ., MARINKOVSKI,D.: Experiments in VTI with semiconductor strain gauges on monoblock wind tunnel balances, in Proc. 8th International Symposium on Strain-Gauge Balance, RUAG, Lucerne, SWITZERLAND, 2012, pp. 1-8.

[12] 30 Series Micro Servo Valves, http://www.moog.com/content/dam/moog/literature/ICD/MoogValves-30series-datasheet-en.pdf

\title{
Sistem za merenje prigušnih derivativa u aerotunelu T-38 metodom prinudnih oscilacija
}

\begin{abstract}
U ovom radu opisan je sistem za merenje prigušnih derivativa pri oscilatornom kretanju modela letelice u radnom delu aerotunela. Metoda prinudnih oscilacija koristi se za merenje dinamičkih derivativa stabilnosti u aerotunelu T-38. Prikazani su uređaji koji se koriste u eksperimentima sa oscilatornim kretanjem modela u ravni propinjanja/skretanja i valjanja. Model se pobuđuje da vrši oscilatorno kretanje pomoću hidrauličnog pogonskog mehanizma. Željeno oscilatorno kretanje modela obezbeđuje se pomoću kontrolne jedinice koja upravlja radom hidrauličnog servo ventila.
\end{abstract}

Ključne reči: aerodinamički derivativi, derivativi stabilnosti, prinudne oscilacije, oscilatorno kretanje, aerodinamički tunel.

\section{Система измерения производных демпфирования в аэродинамической трубе Т-38 методом вынужденных колебаний}

В этой работе описана система измерения производных демпфирования при колебательном движении модели самолёта в рабочей части аэродинамической трубы. Метод вынужденных колебаний используется для измерения динамических производных устойчивости в аэродинамической трубе Т-38. Показаны устройства, используемые в 
экспериментах с колебательным движением модели на уровне резкого подъёма / поворота и качения поверхности. Модель приводится в движение, чтобы совершать колебательные движения, используя гидравлический приводной механизм. Требуемое колебательное движение модели обеспечивается контрольным блоком управления, который управляет работой гидравлического сервоклапана.

Ключевые слова: аэродинамические производные, производные устойчивости, вынужденные колебания, колебательное движение, аэродинамическая труба.

\title{
Système de mesurage des dérivatifs amortisseurs dans la soufflerie $T$ - 38 par la méthode des oscillations forcées
}

\begin{abstract}
Dans ce papier on a décrit le système de mesurage des dérivatifs amortisseurs lors du mouvement oscillatoire du modèle d'aéronef dans la chambre d'expérience de la soufflerie. La méthode des oscillations forcées est utilisée pour le mesurage des dérivatifs dynamiques de stabilité dans la soufflerie T-38. On a présenté les instruments qui étaient utilisés dans les expérimentations avec le mouvement oscillatoire du modèle sur le plan de tangage / déviation et roulement. Le modèle a été incité pour faire le mouvement oscillatoire au moyen d'un propulseur hydraulique. Le mouvement oscillatoire désiré du modèle était assuré par l'unité de contrôle qui dirige le fonctionnement de la soupape servo hydraulique.
\end{abstract}

Mots clés: dérivatifs hydrodynamiques, dérivatifs de stabilité, oscillations forcées, mouvement oscillatoire, soufflerie. 